\title{
KONDISI PENCEMARAN LINGKUNGAN PERAIRAN DI TELUK JAKARTA
}

\author{
Oleh : \\ Suhendar I. Sachoemar dan Heru Dwi Wahjono \\ Peneliti BPPT
}

\begin{abstract}
The environment of the rivers surround Jakarta was polluted due to the increasing of the domestics and industrial waste as response to the rapid development of the anthropogenic activities within the city since the decades. As consequence, the carrying capacity of the water ecosystem was degraded including Jakarta Bay as the estuary of the passing rivers of the Jakarta City. This article briefly discusses the pollution problem within the Jakarta Bay that is supported by the data collected from various sources including the result from in-situ survey. The result has shown the fact of what the causing factors that stimulated the pollution problem within this area.
\end{abstract}

Katakunci : Pencemaran Lingkungan Perairan. Teluk Jakarta, Pantai Utara Jakarta, Air Limbah Domestik, Beban Pencemaran.

\section{PENDAHULUAN}

\subsection{Latar Belakang}

Penurunan kualitas air tanah dan air permukaan yang terjadi saat ini di Jakarta tidak lagi disebabkan oleh industri sebagai penyebab utama yang membuang limbahnya ke badanbadan sungai di wilayah Jakarta. Data hasil penelitian JICA pada gambar 1 di bawah ini menyimpulkan bahwa air limbah domestik adalah penyebab utama penurunan kualitas air sungaisungai di Jakarta. Pada tahun 1989 tercatat kontribusi air limbah domestik sebanyak 78,9\% sedangkan air limbah industri hanya $8 \%$. Pada tahun 2010 perkiraan kontribusi air limbah domestik akan menurun sekitar $72.7 \%$ sedangkan air limbah industri akan meningkat menjadi 9,9\%, (JICA, 1990).

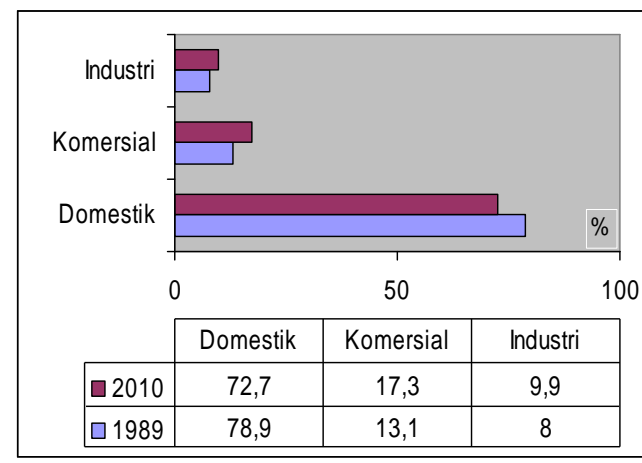

Gambar 1. Grafik Prosentase Sumber

Pencemaran Air Limbah di Jakarta

Selama ini masyarakat cenderung menyalahkan industri terhadap kondisi pencemaran lingkungan perairan yang terjadi di wilayah mereka. Dari hasil survei oleh JICA tersebut masyarakat perlu merubah cara pandang masalah pencemaran yang terjadi saat ini. Limbah cair domestik yang tidak lain adalah air limbah yang dihasilkan dari kegiatan rumah tangga masyarakat menjadi penyebab terbesar terjadinya pencemaran di wilayah perairan teluk Jakarta.

\subsection{Tujuan dan Sasaran}

Kegiatan ini bertujuan untuk melakukan survei dan analisis terhadap kondisi pencemaran yang terjadi di wilayah perairan teluk Jakarta. Adapun sasarannya adalah mendidik masyarakat mengenai cara pandang terhadap masalah pencemaran lingkungan perairan yang selama ini salah. Dengan menampilkan data dan fakta yang aktual diharapkan masyarakat mau merubah pola pikir dan cara hidupnya, yakni khususnya mengenai masalah air limbah domestik yang dihasilkan oleh masyarakat itu sendiri.

\section{PENCEMARAN DI PERAIRAN TELUK JAKARTA}

\subsection{Kematian Masal Ikan di Pantai Utara Jakarta}

Wilayah perairan teluk Jakarta yang berbentuk semi tertutup telah menerima beban berat bahan pencemar baik berupa limbah domestik, organik, industri, logam berat maupun tumpahan minyak yang cenderung meningkat dari waktu ke waktu hingga dikhawatirkan telah melebihi daya dukungnya. Dampak penurunan kualitas perairan Teluk Jakarta ini bahkan telah terasa sampai ke Perairan Kepulauan Seribu yang jaraknya lebih dari $50 \mathrm{~km}$ terutama untuk logam berat seperti ditunjukkan pada tabel 1 dan gambar 2 di bawah ini. Warna kuning dan merah menunjukkan temperatur dan tingkat pencemaran khlorofil yang terjadi di pantai jakarta sampai ke Kepulauan Seribu. 
Tabel 1: Tabel Kualitas Perairan Di Kepulauan Seribu.

\begin{tabular}{|c|c|c|c|c|c|c|}
\hline Wilayah & \multicolumn{2}{|c|}{ Selatan } & \multicolumn{2}{|c|}{ Tengah } & \multicolumn{2}{|c|}{ Utara } \\
\hline Parameter & 1997 & 2003 & 1997 & 2004 & 1997 & 2004 \\
\hline Suhu & 29.5 & 29.4 & 29.1 & 29.4 & 29 & 30.3 \\
\hline Salinitas & 32 & 33 & 32 & 30.1 & 32 & \\
\hline $\begin{array}{l}\text { Kecerahan } \\
(\mathrm{BM}:>3)\end{array}$ & 3.75 & & 5.5 & 6.6 & 8 & 13.6 \\
\hline Arus & 0.09 & & 0.09 & 0.15 & 0.05 & \\
\hline $\begin{array}{l}\mathrm{pH} \\
\text { (BM:6-9) }\end{array}$ & 7.5 & 8.3 & 7.5 & 7.3 & 7.5 & 6.6 \\
\hline $\begin{array}{l}\text { DO } \\
(\mathrm{BM}:>4)\end{array}$ & 6.4 & 6.8 & 5.7 & 7.2 & 4.4 & 7.0 \\
\hline $\begin{array}{l}\text { BOD } \\
(B M:<45)\end{array}$ & 2.7 & 3.4 & 1.9 & & 1.9 & \\
\hline $\begin{array}{l}\text { COD } \\
(B M:<80)\end{array}$ & 162.3 & 89.3 & 149.8 & & 119.9 & \\
\hline Silika & 0.011 & 0.009 & & 0.01 & & \\
\hline $\begin{array}{l}\text { Oil } \\
(\mathrm{BM}:<5)\end{array}$ & $<0.001$ & & $\begin{array}{r}<0.0 \\
01 \\
\end{array}$ & & $<0.001$ & \\
\hline $\begin{array}{l}\text { DIN } \\
(\mathrm{BM}:<1)\end{array}$ & 0.108 & 0.021 & 0.038 & 0.182 & 0.064 & 0.836 \\
\hline Fosfat & 0.01 & & 0.018 & 0.004 & 0018 & \\
\hline $\begin{array}{l}\mathrm{Pb} \\
(\mathrm{BM}:<0.01)\end{array}$ & 0.005 & 0.01 & 0.008 & & 0.008 & \\
\hline $\begin{array}{l}\mathrm{Cu} \\
(\mathrm{BM}:<0.06)\end{array}$ & 0.138 & 0.029 & 0.135 & & 0.209 & \\
\hline $\begin{array}{l}\mathrm{Cd} \\
(\mathrm{BM}:<0.01)\end{array}$ & 0.028 & & 0.054 & & 0.02 & \\
\hline $\begin{array}{l}\mathrm{Hg} \\
(\mathrm{BM}:<0.003)\end{array}$ & 0.056 & & 0.038 & & 0.025 & \\
\hline
\end{tabular}

Sumber : Anonim (2004)

Keterangan :

- Selatan : P. Untung Jawa, P. Pari, P. Kongsi

- Tengah : P. Tidung, Pramuka, Panggang, Semak Daun, Karang Cangkok, Karang Bongkok

- Utara : P. Kelapa

- BM : Baku Mutu

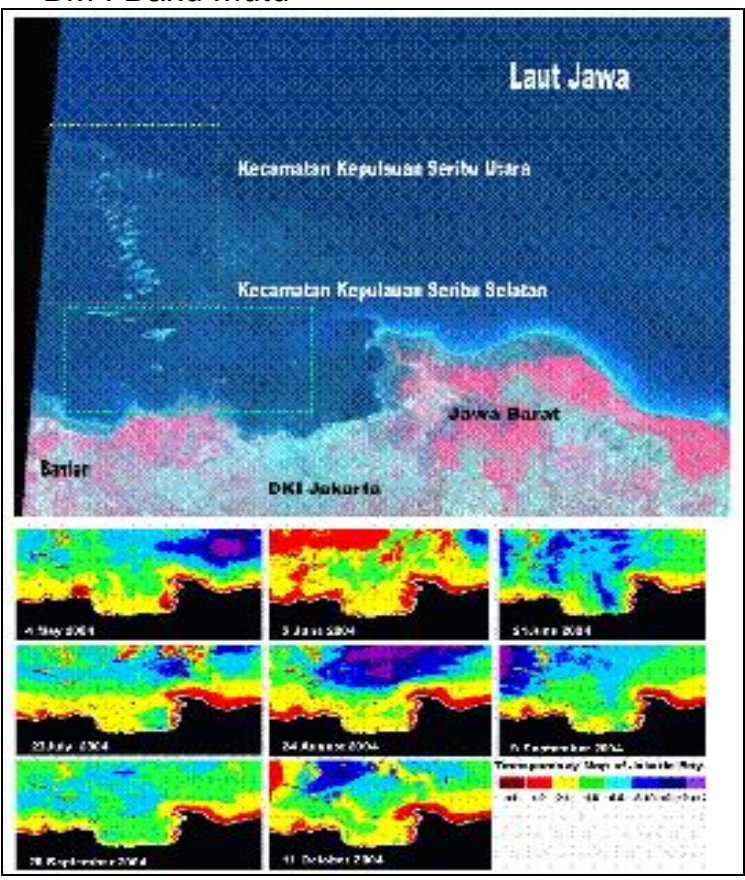

Sumber : Wouthuysen (2004), Unpublished

Gambar 2 : Citra Satelit Kondisi Perairan di Kepulauan Seribu.
Bermuaranya beberapa sungai yang melintasi wilayah DKI Jakarta ke perairan Teluk Jakarta telah membawa berbagai bahan pencemar. Maka tidak mengherankan apabila perairan Teluk Jakarta saat ini telah mengalami pengkayaan berlebihan (eutrofikasi) yang sangat potensial menyebabkan terjadinya ledakan (blooming) plankton atau yang lebih parah lagi menyebabkan terjadinya RED TIDE yang diikiuti dengan penurunan oksigen secara tiba-tiba. Kondisi ini sangat tidak menguntungkan baik secara ekologis, ekonomis maupun estetika, sehingga perlu diminimalisir kemungkinan terjadinya atau bahkan dicegah sama sekali.

Beberapa kejadian kematian masal dari ikan-ikan di Teluk Jakarta beberapa tahun ini sering terdengar. Tabel 2 di bawah ini berisi data waktu, kondisi dan lokasi kematian masal ikan di teluk Jakarta. Informasi lebih detail dapat dilihat pada lampiran tulisan ini. Meskipun beberapa pakar masih belum dapat memastikan penyebabnya, tetapi tidak dipungkiri lagi bahwa kematian massal ikan-ikan tersebut berkaitan erat dengan tidak mencukupinya kadar oksigen terlarut (DO) untuk mendukung kehidupan ikan dan biota perairan lainnya di dalam perairan atau keracunan bahan pencemar lainnya. Terdapat banyak kemungkinan penyebab terjadinya penurunan oksigen dalam perairan yaitu dapat disebabkan oleh ledakan plankton atau peristiwa upwelling yaitu proses penaikan massa air bagian dalam ke permukaan.

Tabel 2 : Waktu dan Lokasi Peristiwa Kematian Masal Ikan di Teluk Jakarta.

\begin{tabular}{|c|c|c|}
\hline Tanggal & Kondisi & Lokasi \\
\hline $\begin{array}{c}07 \mathrm{Apr} \\
2004\end{array}$ & $\begin{array}{l}\text { Air laut berwarna } \\
\text { kemerahan }\end{array}$ & $\begin{array}{l}\text { Pantai Ancol (M. Bintang } \\
\text { Mas-K Japat) Meluas ke P. } \\
\text { Nirwana, P. Bidadari, P. } \\
\text { Damar, P. Onrus }\end{array}$ \\
\hline $\begin{array}{c}30 \text { Nop } \\
2004\end{array}$ & $\begin{array}{l}\text { Air laut tenang (pasang } \\
\text { duduk) dan malamnya } \\
\text { terjadi hujan, air berwarna } \\
\text { kecoklatan (tingkat } \\
\text { kekeruhan cukup tinggi) }\end{array}$ & $\begin{array}{l}\text { Muara Marina sampai Hotel } \\
\text { Horison }\end{array}$ \\
\hline $\begin{array}{c}13 \mathrm{Apr} \\
2005\end{array}$ & Air laut keruh & $\begin{array}{l}\text { Hotel Horison, Pantai } \\
\text { Festival, Pantai marina, } \\
\text { Pantai Karnaval }\end{array}$ \\
\hline $\begin{array}{l}15 \text { Jun } \\
2005\end{array}$ & $\begin{array}{l}\text { air laut keruh, dan pada } \\
\text { saat tersebut terjadi hujan } \\
\text { lebat }\end{array}$ & $\begin{array}{l}\text { Pantai Marina, Pantai } \\
\text { Festival, Pantai H. Mecure, } \\
\text { P. Bandar Jakarta, Pantai } \\
\text { Karnaval }\end{array}$ \\
\hline $\begin{array}{l}5 \text { Agt } \\
2005\end{array}$ & $\begin{array}{l}\text { Air laut berwarna coklat } \\
\text { kemerahan, dimana } \\
\text { sample air laut di pinggir } \\
\text { pantai berwarna coklat, } \\
\text { sample air laut di tengah } \\
\text { laut berwarna merah }\end{array}$ & $\begin{array}{l}\text { Pulau Zukung Sekati, P. } \\
\text { Panggang, P. Pramuka, P. } \\
\text { Karya }\end{array}$ \\
\hline $\begin{array}{c}16 \mathrm{Okt} \\
2005\end{array}$ & $\begin{array}{l}\text { Air laut keruh, Sore hari } \\
(15 / 10) \text { terjadi hujan deras }\end{array}$ & Pantai Ancol \\
\hline
\end{tabular}

Sumber : BPLHD Prop. DKI, Mei 2005 
Data kualitas air laut di perairan teluk Jakarta pada saat kejadian kematian masal ikan tahun 2004 dapat dilihat pada tabel 3 di bawah ini. Gambar 3 menunjukkan ikan-ikan yang mati di pantai utara Jakarta pada saat kejadian tersebut.

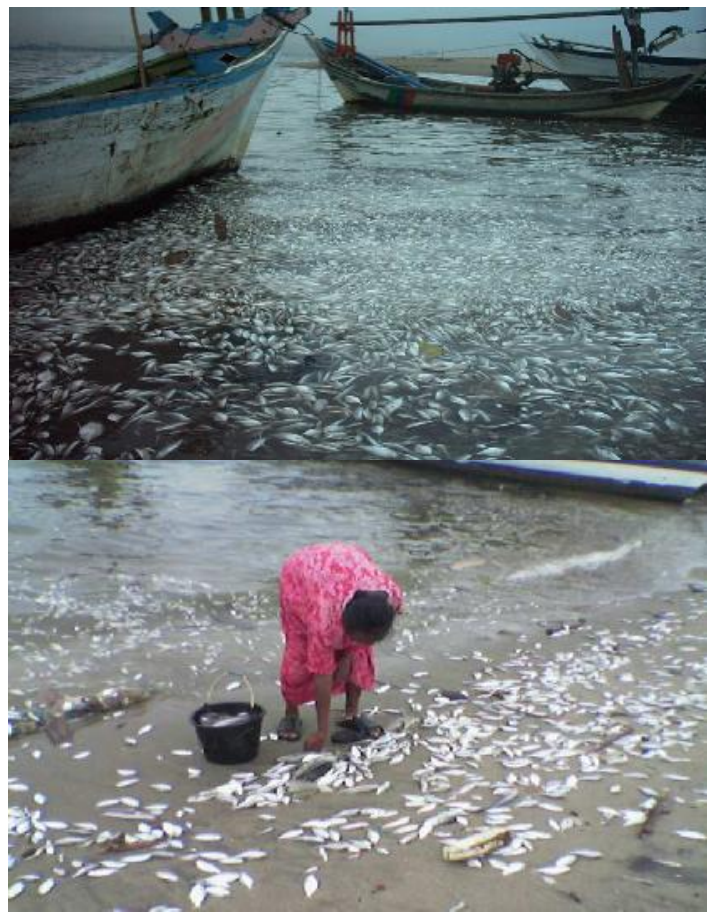

Gambar 3 : Foto Kematian Ikan di Pantau Utara Jakarta Tahun 2004.

Tabel 2. Kualitas Air Laut Pada Saat Kematian Masal Ikan di Teluk Jakarta

\begin{tabular}{|l|l|l|l|l|l|l|}
\hline \multirow{2}{*}{$\begin{array}{c}\text { Para } \\
\text { Meter }\end{array}$} & \multicolumn{3}{|c|}{ Pantai } & \multicolumn{3}{c|}{ Baku Mutu } \\
\cline { 2 - 7 } & Min & Max & Rerata & Biota & Wisata & $\begin{array}{l}\text { Pela- } \\
\text { buhan }\end{array}$ \\
\hline DO & $\mathbf{0 . 5 4}$ & $\mathbf{4 . 4 6}$ & $\mathbf{2 . 3 6}$ & $>5$ & $>5$ & - \\
\hline BOD & $\mathbf{2 1 . 1}$ & $\mathbf{2 8 . 6}$ & $\mathbf{2 5 . 8 4}$ & 10 & 20 & 20 \\
\hline NH3 & 0.07 & $\mathbf{4 . 4 6}$ & $\mathbf{1 . 5 5}$ & * & 0.3 & 0.3 \\
\hline Nitrat & $\mathbf{0 . 0 1}$ & $\mathbf{0 . 1 2}$ & $\mathbf{0 . 0 6}$ & 0.008 & 0.008 & 0.008 \\
\hline Fosfat & $\mathbf{0 . 0 5}$ & $\mathbf{0 . 9 9}$ & $\mathbf{0 . 3 6}$ & 0.015 & 0.015 & 0.015 \\
\hline Sulfida & $\star$ & $\mathbf{0 . 0 6}$ & $\mathbf{0 . 0 3}$ & & 0.01 & 0.01 \\
\hline $\begin{array}{l}\text { Seny. } \\
\text { Aktif } \\
\text { Biru } \\
\text { Metilen }\end{array}$ & 0.16 & $\mathbf{1 . 2 1}$ & 0.47 & 0.001 & 1 & 1 \\
\hline
\end{tabular}

Sumber : BPLHD Prop. DKI, Mei 2005

\subsection{Kualitas Perairan Teluk Jakarta}

Di daerah yang tingkat pencemarannya cukup tinggi, proses upwelling akan menyebabkan terjadinya proses pengadukan bahan organik yang terdapat dan terakumulasi di dasar perairan kepermukaan. Massa air yang miskin kadar oksigennya ini secara otomatis akan memicu kematian massal pada ikan dan biota perairan lainnya. Pemicunya proses ini dapat berupa arus atau pun aliran sungai yang berlebihan. Peristiwa seperti ini secara periodik sering ditemukan di Kawasan Budidaya Perikanan Air Tawar di Wilayah Saguling, Cirata dan Jatiluhur (Jawa Barat). Untuk itu kita perlu waspada dan mencermatinya kejadian tersebut dengan mengembangkan berbagai kegiatan penelitian, pemantauan, pengendalian kualitas air sungai dan pengendalian aktifitas yang dapat menyebabkan terjadi pencemaran baik di sepanjang daerah aliran sungai (DAS) maupun di dalam perairan Teluk Jakarta itu sendiri.

Berdasarkan hasil pemantauan dan laporan Bappedal DKI Jakarta (2004), diketahui bahwa kualitas perairan Teluk Jakarta telah mengalami pencemaran yang cukup parah, sehingga saat ini perairannya telah mengalami penyuburan berlebihan (eutrofikasi) yang diakibatkan oleh pencemaran dari daratan maupun aktifitas pantai dan laut. Kualitas terburuk terdapat di perairan yang dekat dengan pantai (zona D, $5 \mathrm{~km}$ dari pantai) dan semakin ke tengah (zona A, 15-20km) kualitasnya mengalami perbaikan, tetapi karena zona $A$ dekat dengan pantai di barat dan timur maka kualitas perairannya juga mengalami penurunan.

\subsection{Kualitas Fisik Air Teluk Jakarta}

Untuk perairan Teluk Jakarta, dan Muara Teluk Jakarta pada periode Mei dan Oktober untuk parameter suhu, salinitas, $\mathrm{pH}$, arah dan kecepatan angin, masih memenuhi baku mutu dan tidak terdapat perbedaan konsentrasi yang besar antara kedua periode tersebut. Sedangkan untuk parameter DO dan kecerahan telah melebihi baku mutu.

\subsection{Kualitas Kimia Air Teluk Jakarta}

Di perairan Teluk Jakarta konsentrasi detergen dan BOD di semua zona masih memenuhi baku mutu, namun terjadi peningkatan konsentrasi detergen di semua zona selama periode Mei dan Oktober. Sedangkan pada parameter seng secara umum masih memenuhi baku mutu yang ada, hanya di zona-zona tertentu saja. Untuk parameter nitrat di semua zona telah melebihi baku mutu. Untuk Muara Teluk Jakarta, pada saat kondisi surut, parameter BOD dan detergen secara umum di semua zona masih berada di bawah baku mutu, hanya di zona-zona tertentu saja. Sedangkan untuk parameter nitrat di semua zona telah melampui baku mutu. Pada saat pasang, parameter BOD, detergen, dan seng tidak berbeda dengan saat surut yaitu di semua zona telah melebihi baku mutu. Sebaran kualitas DO di Perairan Teluk Jakarta dan Muaranya terlihat pada Gambar 4 dan 5. 


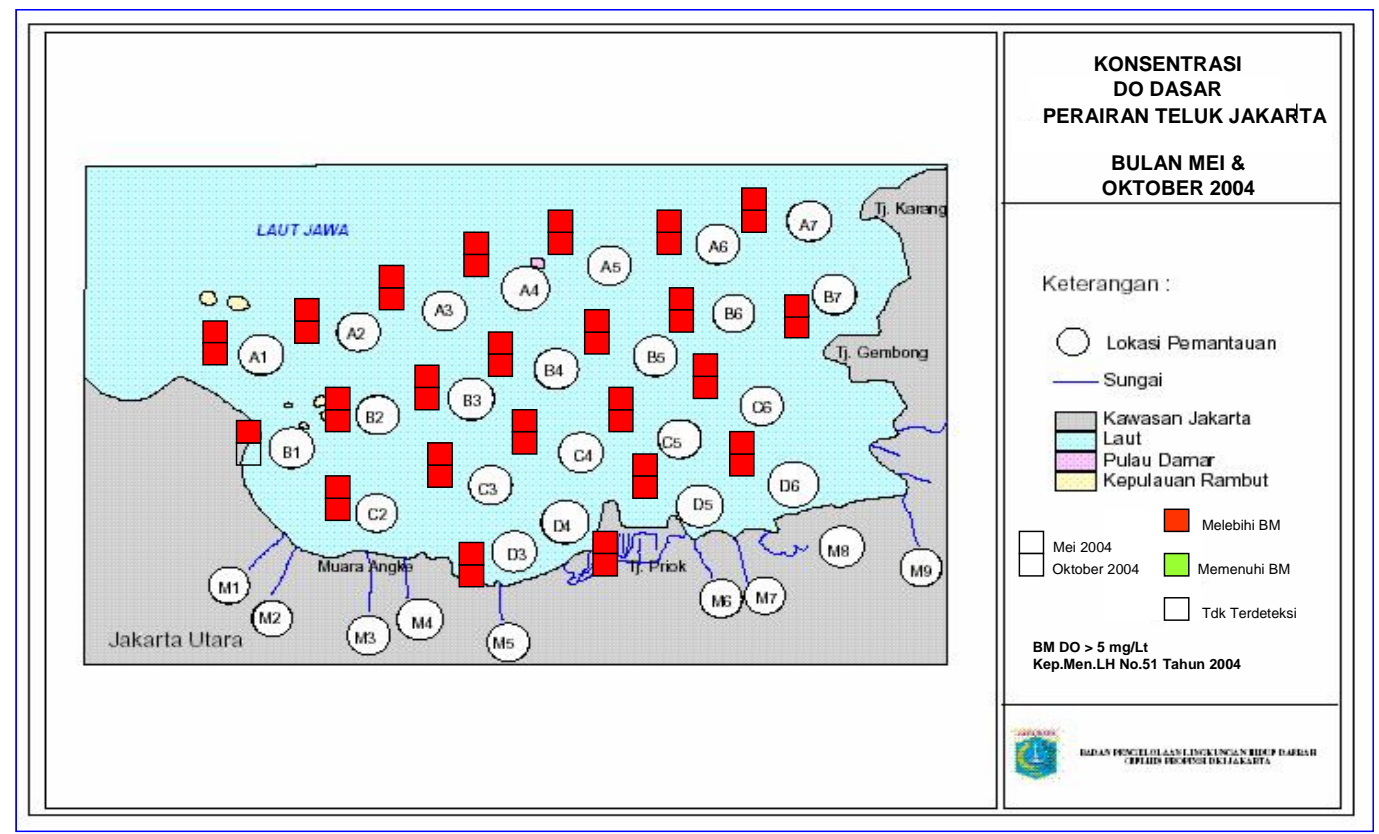

Gambar 4 : Kualitas DO di Perairan Teluk Jakarta Bulan Mei dan Oktober 2004 (BPLHD, 2004).

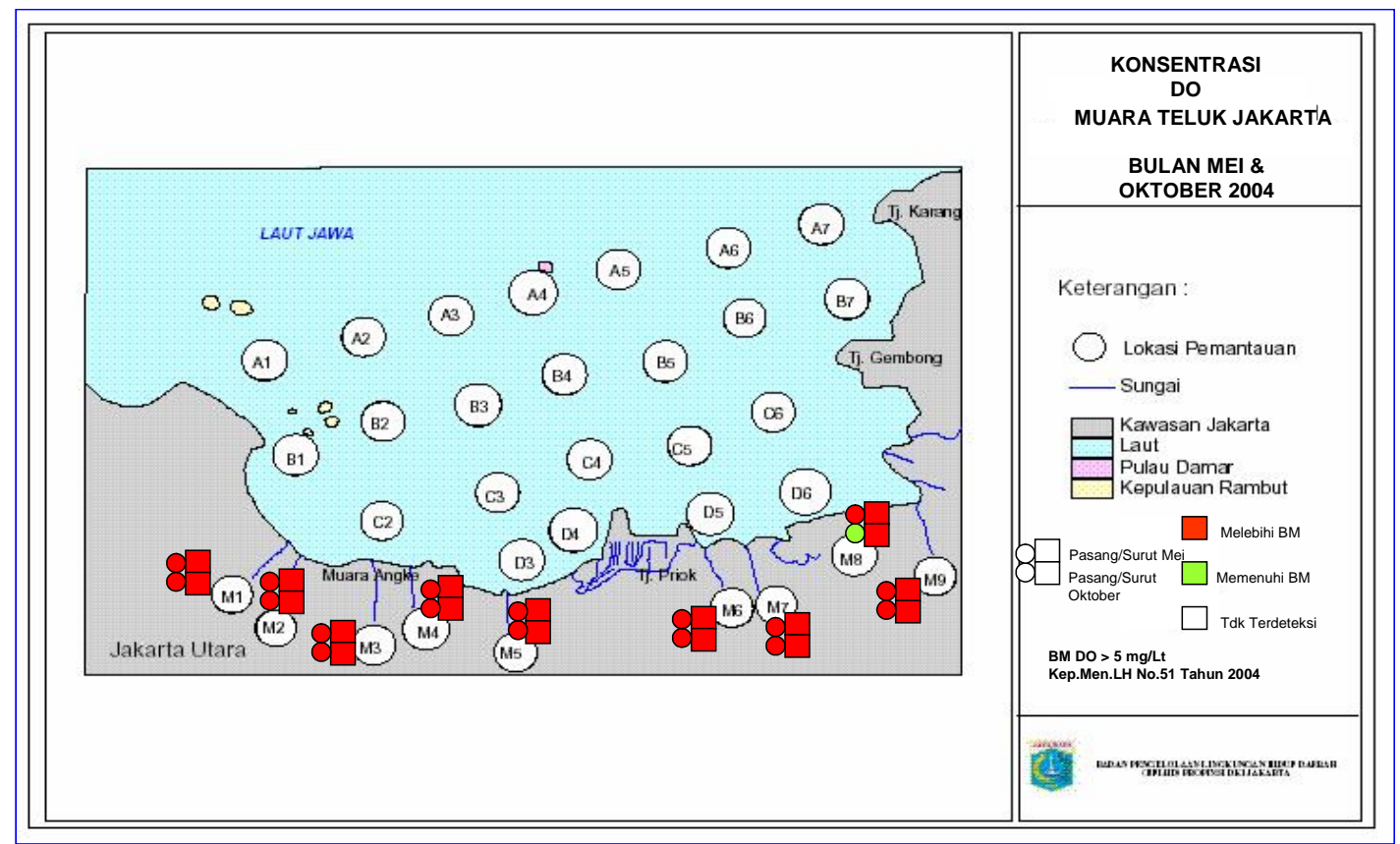

Gambar 5 : Kualitas DO di Muara Teluk Jakarta Pada Kondisi Pasang dan Surut Bulan Mei dan Oktober 2004 (BPLHD, 2004).

\subsection{Kualitas Biologi Air Teluk Jakarta}

Berdasarkan indeks keanekaragaman, perairan Teluk Jakarta untuk zona $D$ telah mengalami pencemaran berat, zona $\mathrm{C}$ mengalami pencemaran sedang dan zona $B$ dan A mengalami pencemaran ringan.
Sedangkan untuk muara Teluk Jakarta, muara Angke, Cengkareng, dan muara Sunter telah mengalami pencemaran berat, muara Kamal, muara Karang, muara Ancol, muara Cakung, muara Marunda mengalami pencemaran sedang, dan muara Gembong mengalami pencemaran ringan (Gambar 6 dan 7). 


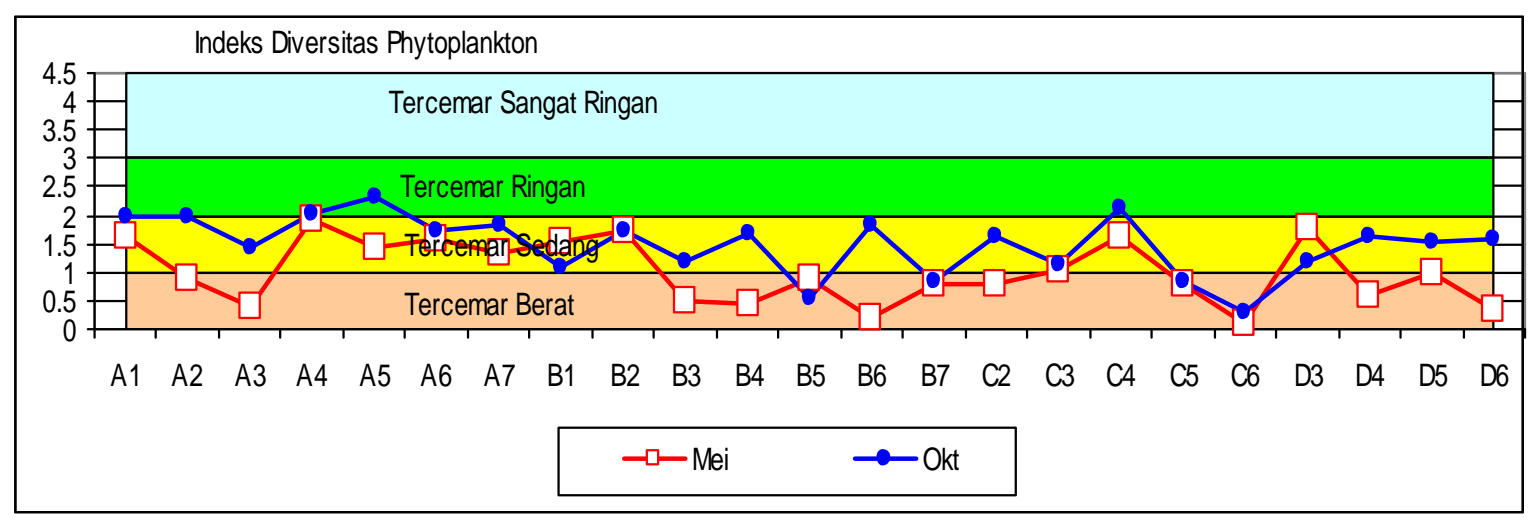

Gambar 6 : Indeks Diversitas di Muara Teluk Jakarta Pada Kondisi Pasang dan Surut Bulan Mei dan Oktober 2004 (BPLHD, 2004).

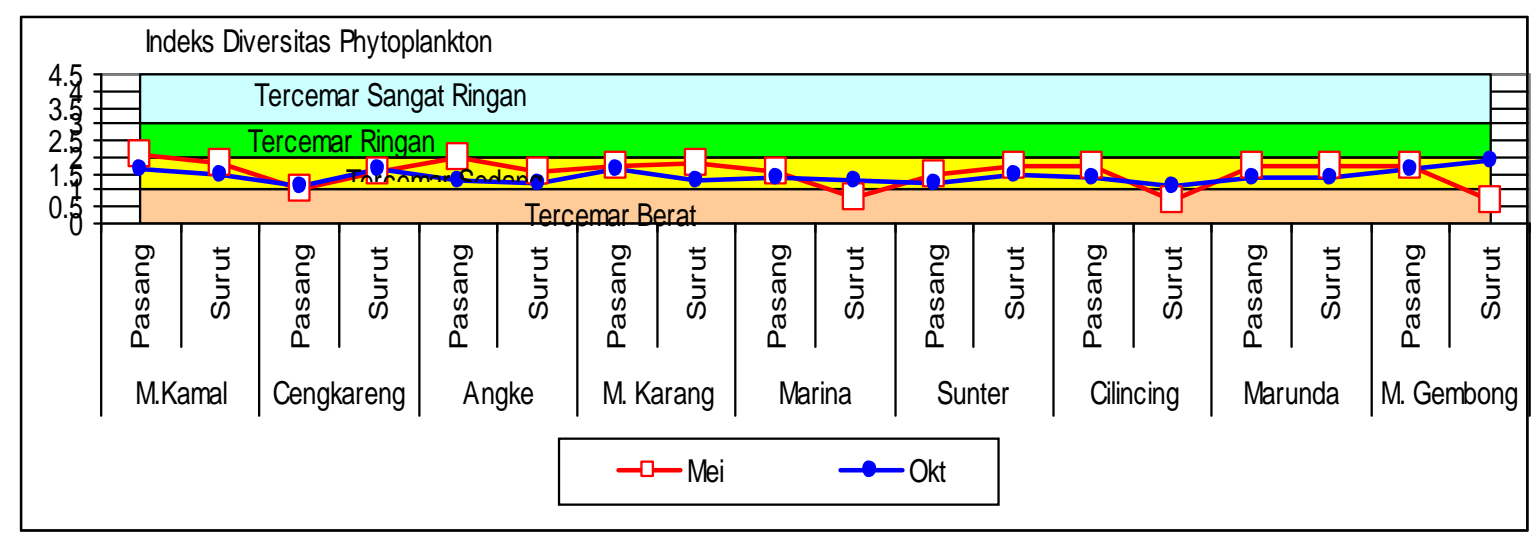

Gambar 7: Indeks Diversitas di Muara Teluk Jakarta Pada Kondisi Pasang dan Surut Bulan Mei dan Oktober 2004 (BPLHD, 2004).

Dari grafik di atas terlihat bahwa muara sungai di wilayah Jakarta telah mengalami pencemaran berat terutama partikel tersuspensi (TSS), ammonia, nitrat, phosphat, Coli dan Fecal Coli. Hal ini juga berkaitan dengan kondisi sungainya yang bermuaran ke Teluk Jakarta telah mengalami pencemaran berat. Bahkan wilayah sebarannya telah sampai ke perairan dengan radius lebih dari $10 \mathrm{~km}$ dari pantai Jakarta. Untuk menjaga keberlanjutannya, nampaknya perlu dilakukan upaya keras dalam mengurangi tingkat pencemaran di Teluk Jakarta dengan menggalakkan dan meningkatkan program PROKASI di seluruh daerah aliran sungai dari hulu sampai ke hilir.

\subsection{Karakteritik dan Pola Perubahan Kualitas Perairan Teluk Jakarta}

Berdasarkan hasil pemantauan BPLHD DKI Jakarta dari tahun 1999 hingga tahun 2004, diketahui bahwa setiap lokasi di perairan Teluk Jakarta mulai dari muara sungai disepanjang pantai hingga perairan lepas pantai memiliki karakteristik dan pola perubahan tertentu yang berhubungan dengan kondisi kualitas perairannya. Hal ini nampaknya berkaitan erat dengan berbagai faktor baik yang berhubungan dengan kondisi kegiatan di daratan yang limbahnya terbawa air sungai maupun kondisi meteorologi dan musim (angin, hujan, kemarau) serta kondisi oceanografi (arus dan pasang surut) dan morfologi pantai. Kombinasi multi faktor ini secara keseluruhan akan mempengaruhi kondisi kualitas air di Teluk Jakarta.

Bentuk perairan Teluk Jakarta yang semi tertutup ini akan menyebabkan terakumulasinya berbagai jenis polutan di sepanjang pantai. Demikian halnya dengan variasi kondisi sungai yang membawa polutan akan berpengaruh terhadap variasi kondisi kualitas air di muara sungai sepanjang pantai Teluk Jakarta. Variasi ini berkaitan erat dengan kondisi meteorologi dan musim seperti curah hujan. Sedangkan penyebaran secara spasial dan vertikal banyak dipengaruhi pola arus dan meteorologi. Kesemua faktor ini dalam menganalisa dan 
mengevaluasi kondisi perairan Teluk Jakarta yang berhubungan dengan berbagai kejadian kerusakan ekosistem perlu diperhatikan dan dicermati secara seksama agar inti permasalahan penyebab terjadinya kerusakan dapat diketahui secara lebih jelas dan solusi pemecahannya sesuai dengan sasaran.

Kadar oksigen terlarut (DO) dan BOD seperti terlihat pada Gambar 8 dan 9 dari periode ke periode terutama dalam periode tahun 2002-2003 mengalami penurunan pada waktu pasang. Sedangkan pada waktu surut kadar BOD cenderung meningkat terutama di muara Cilincing, Marunda dan Bekasi. Sementara DO hampir tidak ada perubahan kecuali di beberapa tempat seperti muara Karang, Angke dan Cengkareng. Secara umum kondisi DO dan BOD di muara-muara sungai sepanjang pantai Teluk Jakarta berada dibawah baku mutu dan tidak layak untuk mendukung kehidupan ikan dan biota laut lainnya, maka tidak mengherankan di kawasan pantai dalam radius kurang dari $5 \mathrm{~km}$ sering terjadi kematian massal pada ikan-ikan.

Kekurangan oksigen ini bisa terjadi karena kelebihan limbah organik yang dapat memicu ledakan plankton pada kondisi tertentu, terutama pada waktu suhu perairan cukup hangat dan tidak ada arus. Melihat kondisi muara sungai yang demikian, tingginya limbah organik diduga pula telah menyebabkan tingginya kadar $\mathrm{H} 2 \mathrm{~S}$ dalam sedimen yang mana apabila teraduk kepermukaan, $\mathrm{H}_{2} \mathrm{~S}$ akan menyebabkan ikan dan biota laut menjadi keracunan. Untuk itu pemantauan kadar DO secara terus menerus di beberapa muara sungai yang cukup rawan akan terjadinya ledakan plankton, sebaiknya dipasang alang pemantau yang dapat secara terus menerus memberikan informasi tentang kondisi kadar oksigen terlarut di perairan.
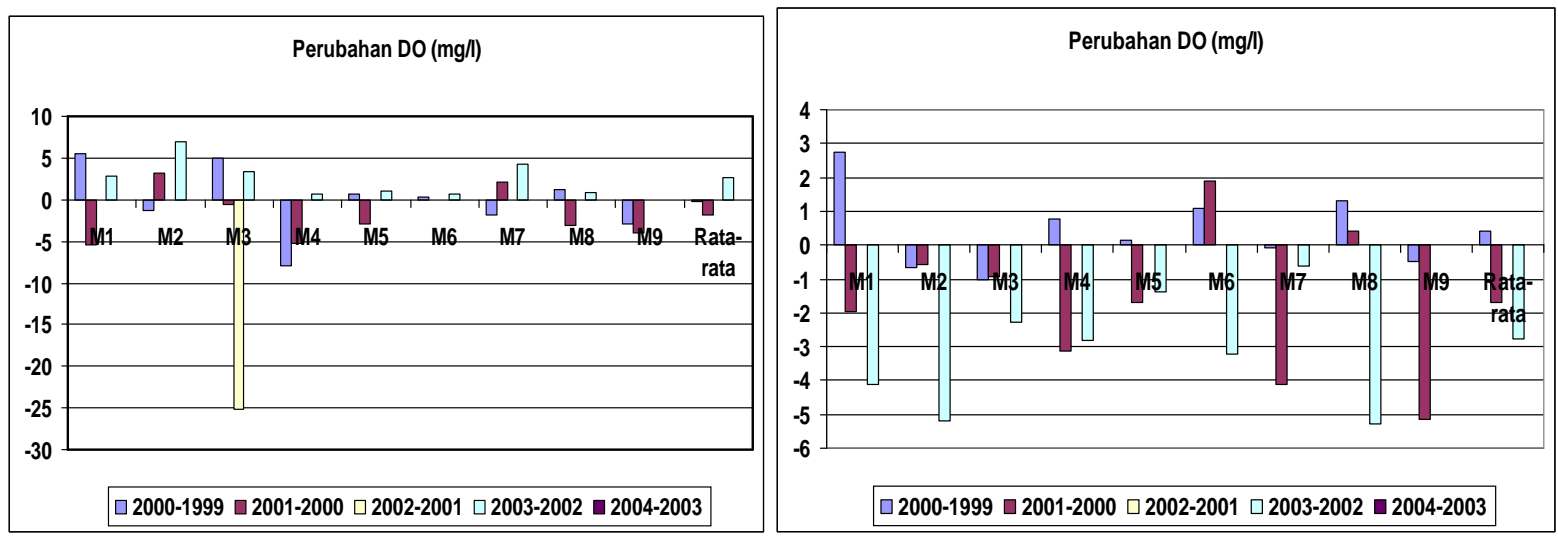

Gambar 8 : Perubahan DO Di Muara Sungai Teluk Jakarta Pada Waktu Surut (Kiri) Dan Pasang (Kanan).
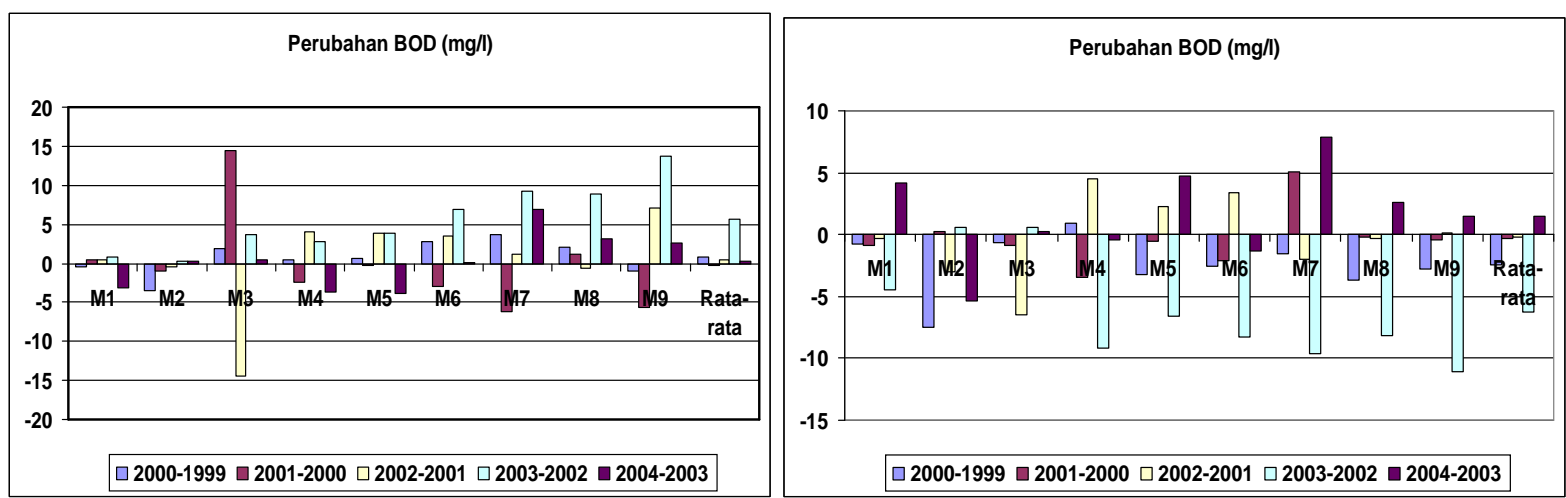

Gambar 9 : Perubahan BOD Di Muara Sungai Teluk Jakarta Pada Waktu Surut (Kiri) Dan Pasang (Kanan). 
Tingginya limbah organik di muara Teluk Jakarta dapat juga terlihat dengan tingginya konsentrasi partikel tersuspensi (TSS), nitrit, ammonia, phosphat dan COD yang melebihi ambang batas di hampir keseluruhan muara sungai Teluk Jakarta. Dari hasil pemantauan selama periode 1999-2004 terlihat bahwa konsentrasi ke lima parameter tersebut cenderung menunjukkan peningkatan terutama pada waktu surut (Gambar 10, 11 dan 12).

Dengan peningkatan konsentrasi pada kelima parameter yang menjadi indikator terjadinya peningkatan limbah organik, maka diduga kadar $\mathrm{H}_{2} \mathrm{~S}$ dalam sedimen akan meningkat pula sebagai akibat terjadinya proses pembusukan. Dengan demikian tidak mengherankan kalau kualitas perairan di muara sungai sangat buruk baik dari segi estetika, bau maupun fungsi ekologisnya. Untuk mengatasinya diperlukan upaya pengerukan dan pembatasan pembuangan limbah organik ke perairan melalui multi regulasi dan koordinasi antar berbagai pihak baik pemerintah, industri dan masyarakat.
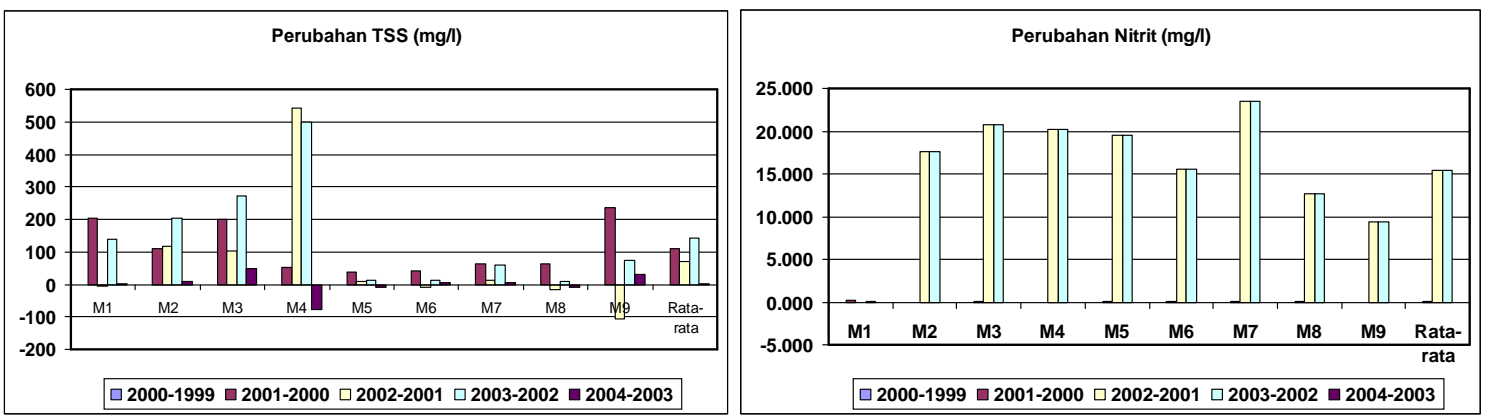

Gambar 10 : Perubahan TSS (Kiri) Dan Nitrit (Kanan) Di Muara Sungai Teluk Jakarta Pada Waktu Surut.
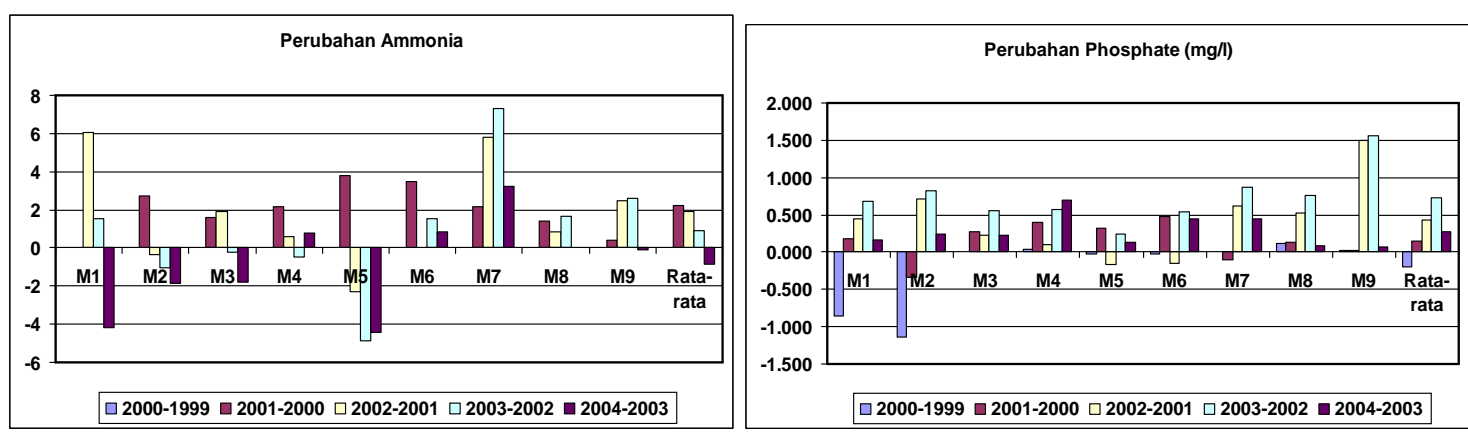

Gambar 11: Perubahan Ammonia (Kiri) Dan Phosphat (Kanan) Di Muara Sungai Teluk Jakarta Pada Waktu Surut.

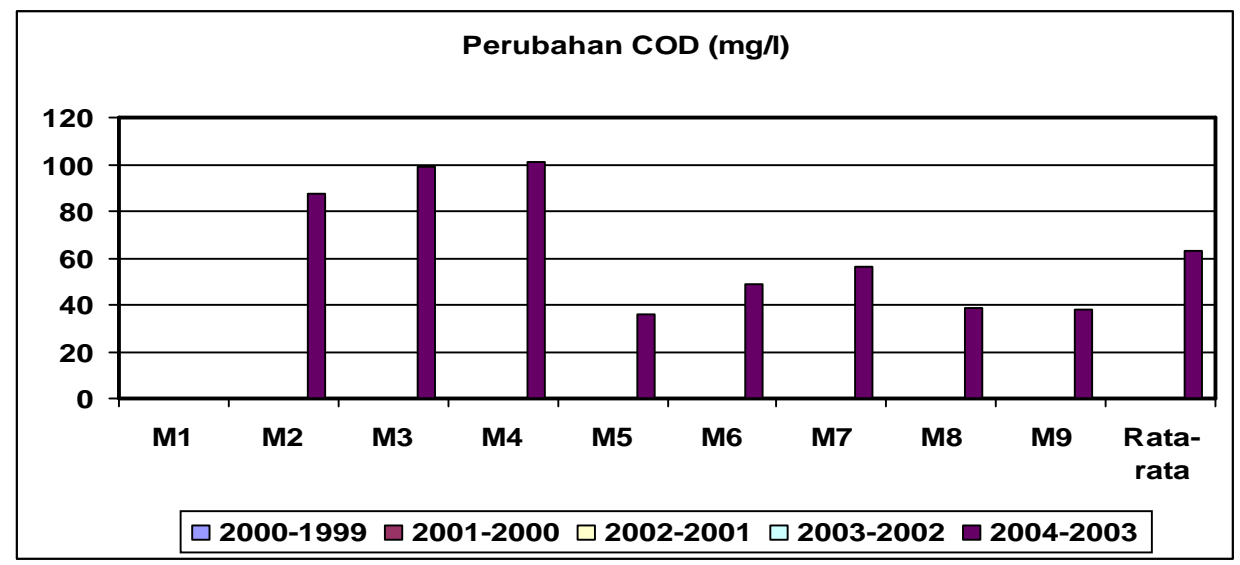

Gambar 12 : Perubahan Konsentrasi COD Di Muara Sungai Teluk Jakarta Pada Waktu Surut. 
Kualitas perairan di Teluk Jakarta semakin jauh dari pantai menunjukkan perbaikan hampir di keseluruhan parameter yang diamati seperti COD, DO, BOD, phosphat, nitrit, TDS, TSS, ammonia, detergen, coliform dan fecal coliform (BPLHD DKI Jakarta, 2004). Keseluruhan nilai parameter tersebut berada dibawah baku mutu yang ditentukan. Namun demikian, hasil pemantauan selama periode 1999-2004, telah menunjukkan adanya indikasi kenaikan kadar DO dan BOD pada periode tahun 1999-2000 dan terjadinya penurunan pada periode tahun 20032004 mulai dari Stasiun D (Gambar 13) yang berjarak $5 \mathrm{~km}$ dari pantai, C (Gambar 14) $10 \mathrm{~km}$ dari pantai, B (Gambar 15) $15 \mathrm{~km}$ dari pantai dan A (Gambar 16) $20 \mathrm{~km}$ dari pantai. Kenaikan dan penurunan konsentrasi $D O$ dan $B O D$ ini nampaknya berhubungan erat dengan terjadinya kenaikan dan penurunan konsentrasi TSS dalam periode yang sama (Gambar 17 dan 18). Sedangkan konsentrasi nitrit (Gambar 19 dan 20) dan detergen (Gambar 21 dan 22) dalam periode tahun 2003-2004 menunjukkan kecenderungan peningkatan. Nampak selain limbah domestik, industri dan minyak, detergen juga menjadi sumber bahan pencemar yang cukup potensial di Teluk Jakarta dan telah menunjukkan kecenderungan peningkatan. Limbah domestik ini perlu dikendalikan penggunaannya dan cara pembuanggannya, sehingga peningkatannya dapat dikurangi.
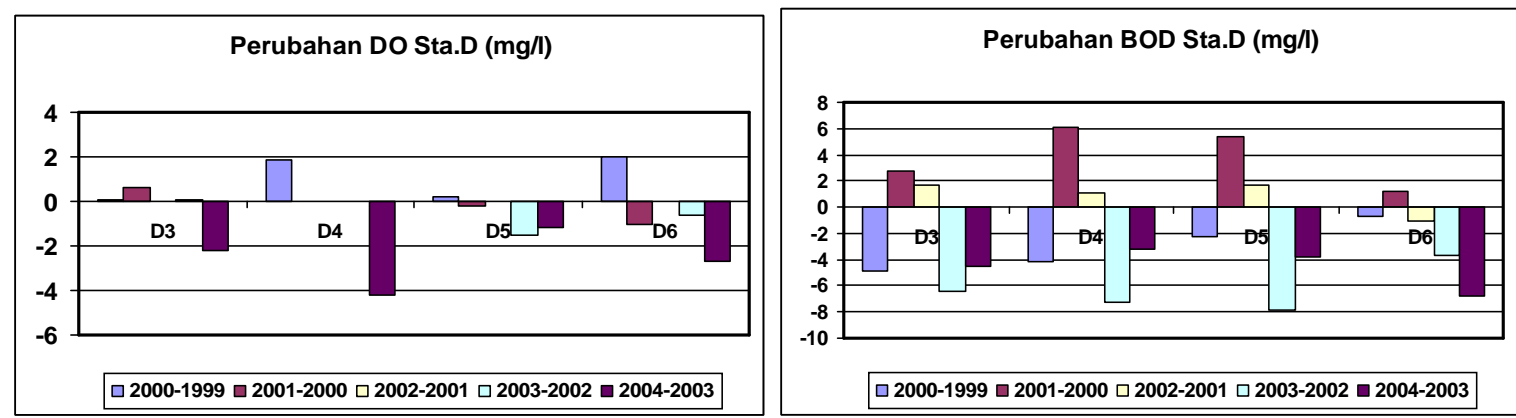

Gambar 13 : Konsentrasi DO (kiri) dan BOD (kanan) di Kelompok Stasiun D.
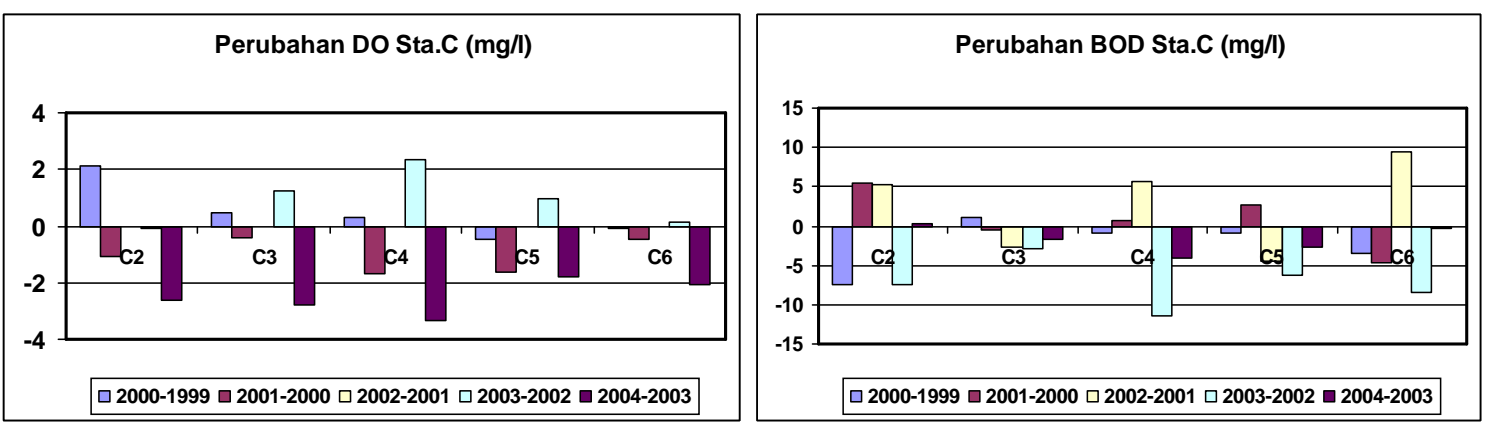

Gambar 14 : Konsentrasi DO (kiri) dan BOD (kanan) di Kelompok Stasiun C.
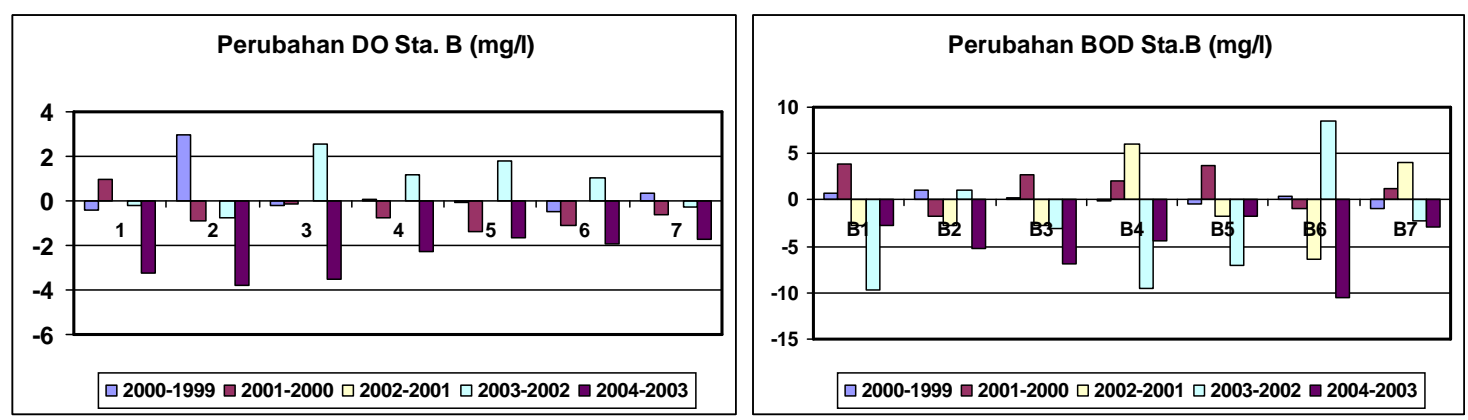

Gambar 15 : Konsentrasi DO (kiri) dan BOD (kanan) di Kelompok Stasiun B. 

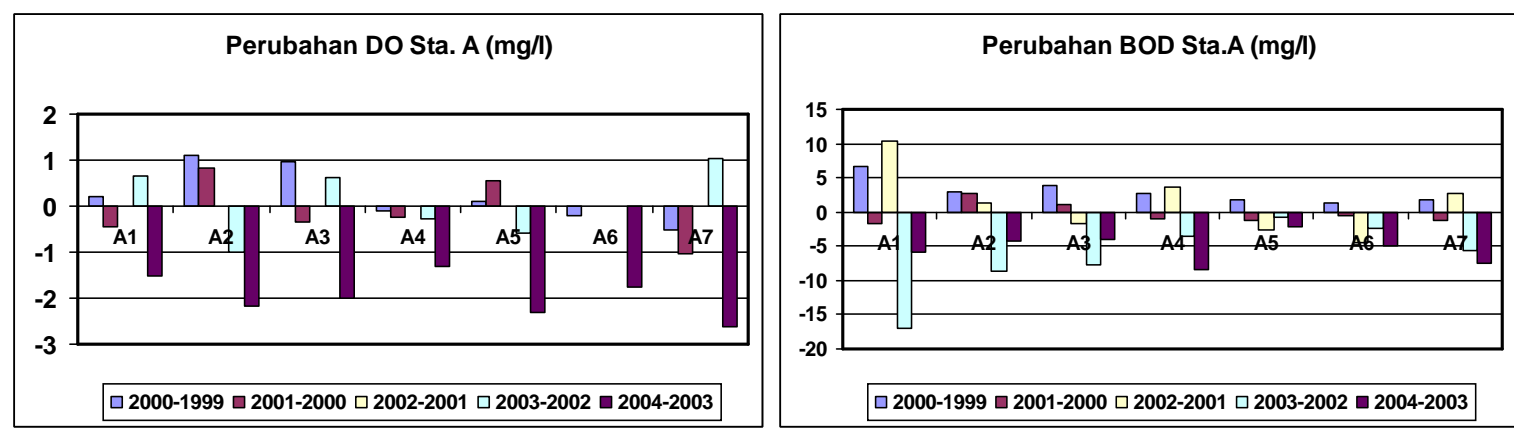

Gambar 16 : Konsentrasi DO (Kiri) dan BOD (Kanan) di Kelompok Stasiun A.
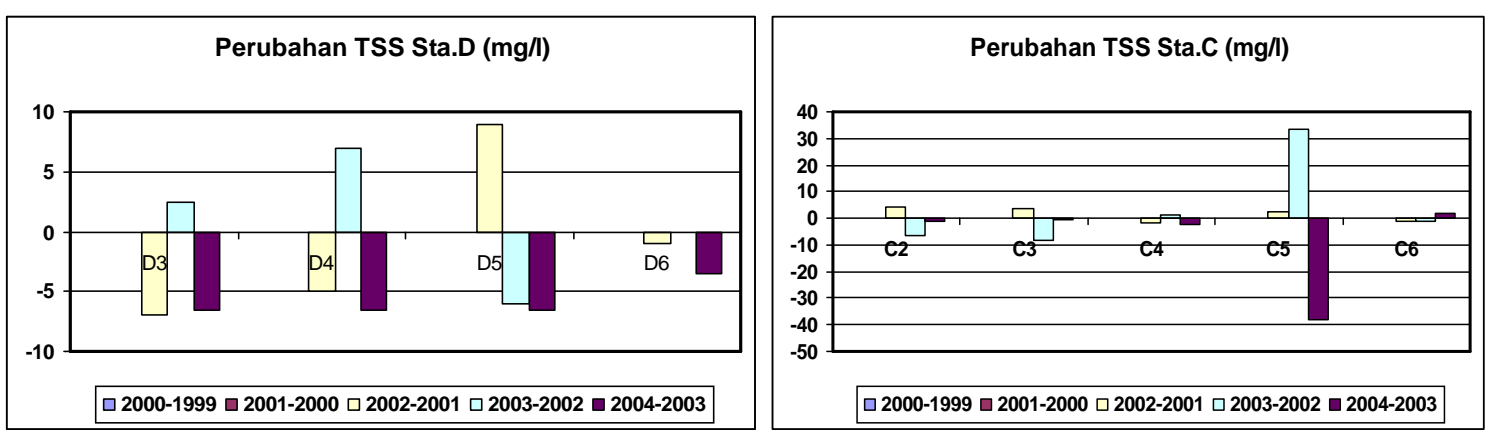

Gambar 17 : Konsentrasi TSS di Kelompok Stasiun D (Kiri) dan C (Kanan).
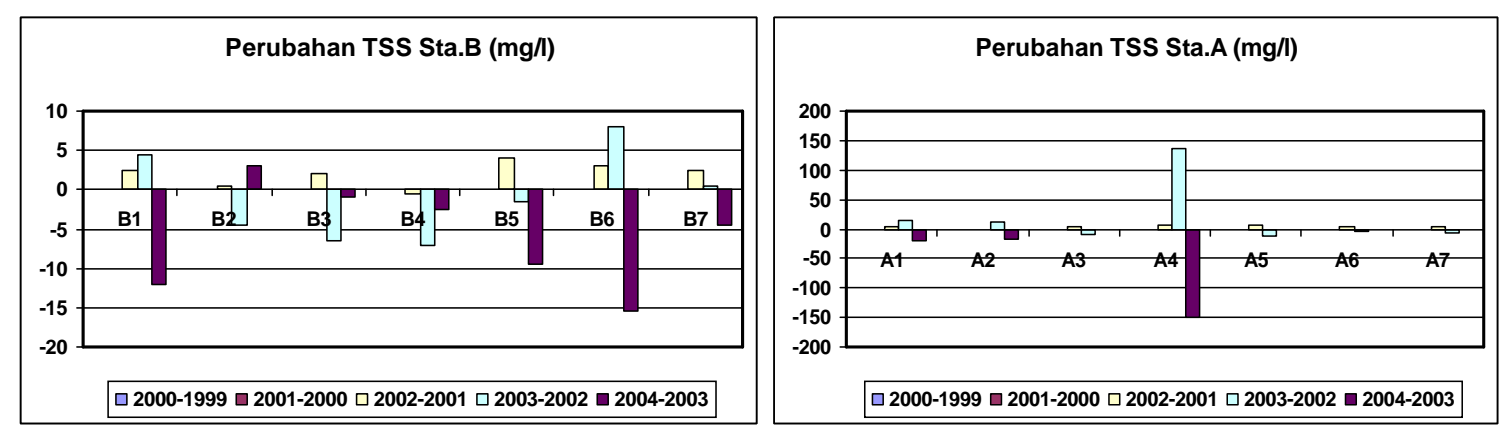

Gambar 18 : Konsentrasi TSS di Kelompok Stasiun B (Kiri) dan A (Kanan).
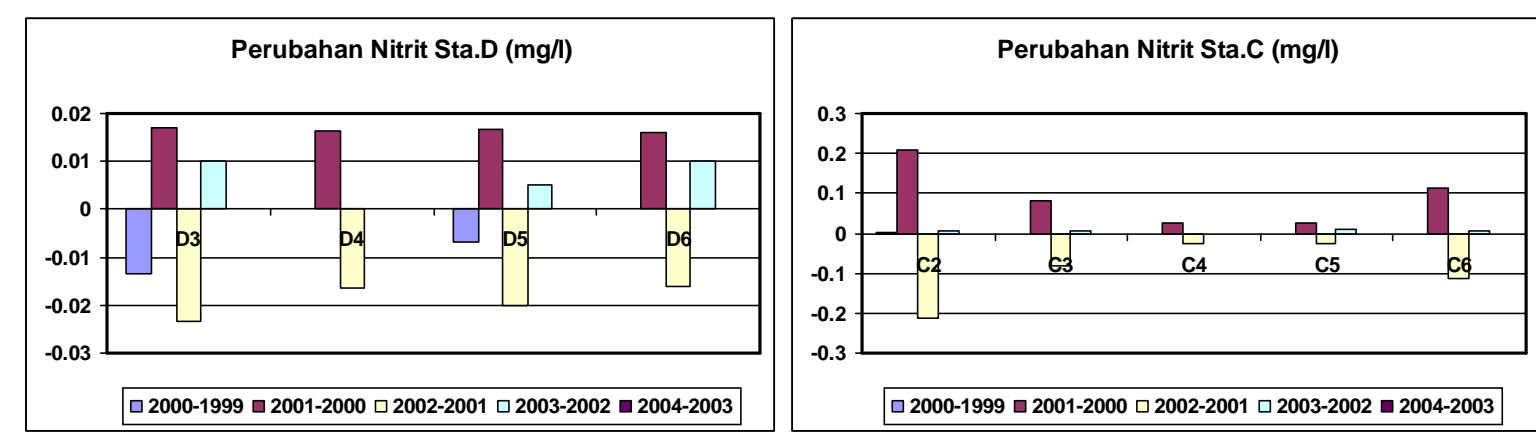

Gambar 19 : Konsentrasi Nltrit di kelompok stasiun D (Kiri) dan C (Kanan). 

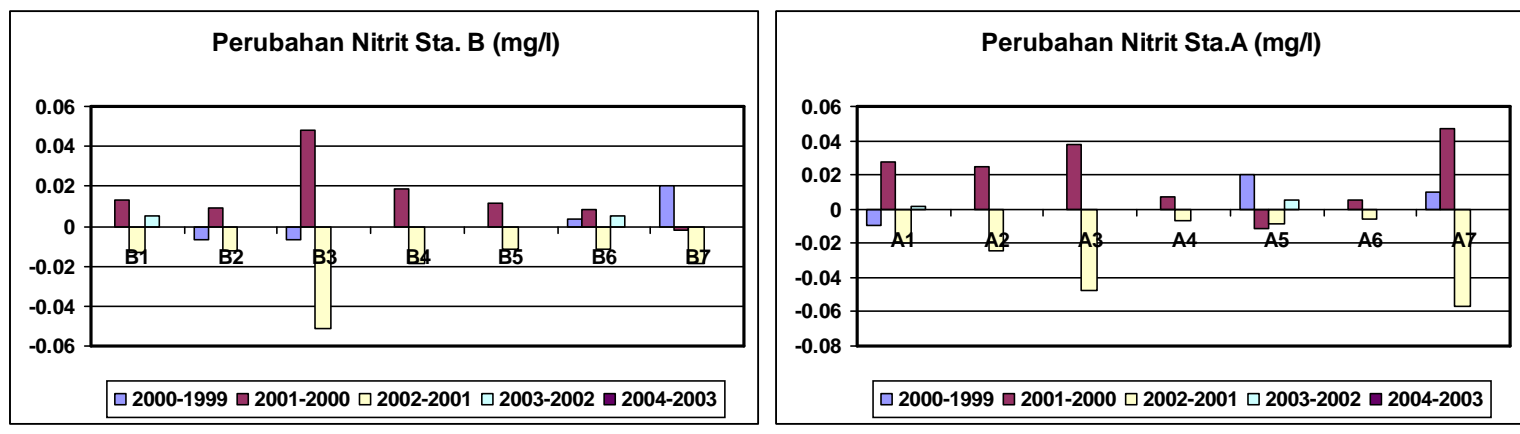

Gambar 20 : Konsentrasi Nltrit di Kelompok Stasiun B (Kiri) dan A (Kanan).
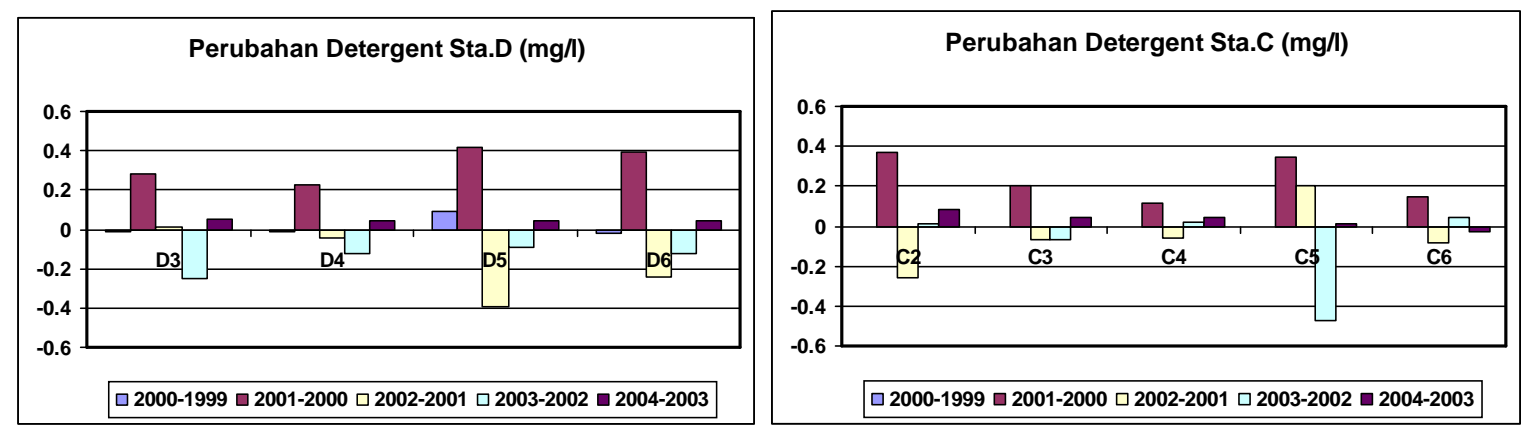

Gambar 21 : Konsentrasi detergen di Kelompok Stasiun D (Kiri) dan C (Kanan).
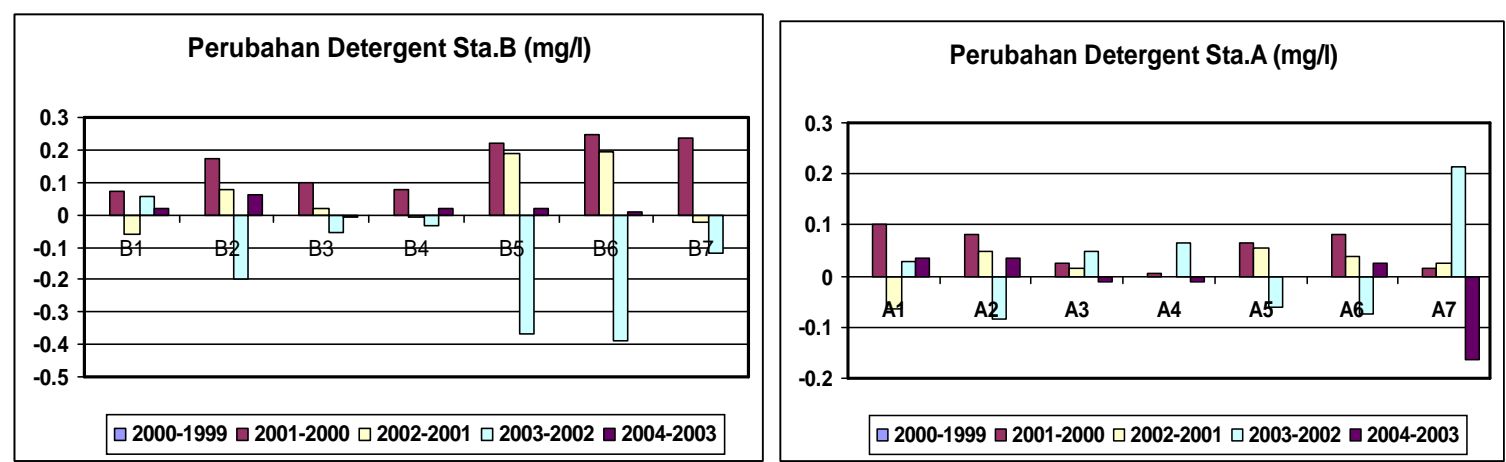

Gambar 22 : Konsentrasi detergen di Kelompok Stasiun B (Kiri) dan A (Kanan).

\section{RED TIDE DAN PARAMETER INDIKATIF}

\subsection{Deskripsi dan Bahaya Red Tide}

Red tide adalah suatu peristiwa atau fenomena terjadinya ledakan populasi phytoplankton (plankton blooms) di perairan pantai (Bates at al, 1998; Peristiwa ini biasanya diikuti oleh kematian massal pada ikan dan biota perairan lainnya yang disebabkan oleh berkurangnya kadar oksigen terlarut (DO) dalam perairan secara tiba-tiba (Clément and Lembeye, 1993). Akibat yang lebih menakutkan dari red tide yaitu apabila yang meledak adalah populasi phytoplankton dari jenis dinoflagellata yang bersifat toxic atau beracun. Biota perairan seperti ikan, kepiting dan kerang-kerangan yang memakan phytoplankton beracun ini apabila termakan manusia, maka akan menyebabkan

keracunan. Karenanya red tide dikenal pula sebagai Paralytic Shellfish Poisoning (PSP) yaitu suatu penyakit keracunan makanan yang disebabkan oleh makanan seafood yang terkontaminasi oleh micro-organisma (plankton) beracun dari lokasi red tide. Keracunan ini bahkan sampai dapat menyebabkan kematian pada manusia. Micro organisma beracun yang terdapat di lokasi red tide dapat berbeda-beda. Sebagai contoh, Alexandrium fundyense banyak ditemukan diperairan sepanjang Pantai Atlantik Utara hingga Kanada dan New England, kemudian ditemukan pula di Pantai Pasifik Barat (California) hingga Alaska. Karonia brevis ditemukan di Teluk Meksiko dan Pantai Barat 
Meksiko. Mikro organisma lainnya yaitu Alexandrim sp, Dinophysis, Pseudinitzia dan lain sebagainya. Berdasarkan informasi medis, microorganisma Alexandrium fundyense tergolong ke dalam micro-organisma yang sangat potensial menyebabkan keracunan. Manusia yang terjangkit PSP akan terkontaminasi racun satoxin yang dalam jangka waktu 30 menit syarafnya akan terganggu. (Fryxell et al, 1997; Bates, S.S. 1998; Fryxell and Hasle, 2004).

Gangguan selanjutnya akan menjalar ke lidah, dagu, muka, leher dan organ tubuh lainnya yang disertai dengan rasa sakit kepala, pusing dan muntah-muntah bahkan dapat menyebabkan sesak napas yang akhirnya akan membawa kematian, tergantung dari tingkat keracunannya. Untuk mencegah terjadinya resiko keracunan atau sindrom PSP, sebaiknya ikan terutama kekerangan yang sifatnya filter feeder yang berasal dari lokasi red tide tidak dikonsumsi. Tetapi untuk udang-udangan, kepiting dan ikanikan bersirip keras cukup aman untuk dikonsumsi. Namun demikian sebaiknya ikan dan udangudangan yang berasal dari lokasi red tide atau perairan yang terpolusi diperiksa terlebih dahulu kadar toksisitasnya sebelum dikonsumsi. Karena walaupun dimasak dengan temperatur tinggi, kadar racunnya tidak berkurang (Orsini et al 2002). Berikut ini contoh micro-organisme plankton yang sering muncul dalam peristiwa red tide (Gambar 23). Di perairan Ancol Jakarta pada waktu terjadinya kematian ikan massal yang diduga disebabkan terjadinya red tide dalam bulan Mei 2004, ditemukan jenis plankton diatom seperti Skletonema, $s p$, Thalassiosira, $s p$, Chaetoceros, $s p$ dan jenis lainnya. Sedangkan dinoflagelata-nya adalah Prorocentrum, $s p$ dan lain-lain.
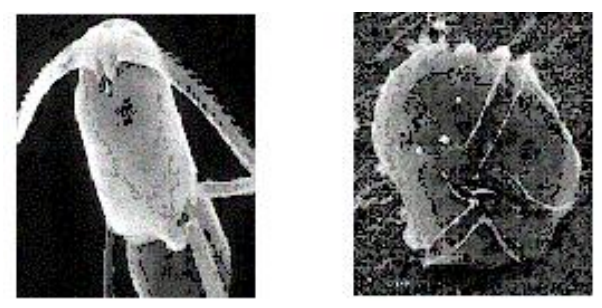

Dinophysis

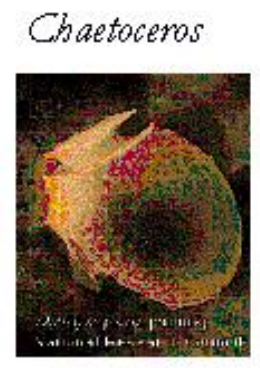

Alexandrium tamarense

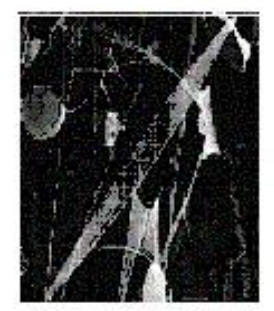

Pseudinitzia
Gambar 23 :Micro-organisma Phyto Plankton Penyebab Red Tide (Fryxell and Hasle, 2004).

\subsection{Parameter Indikatif Red Tide}

Red tide sering terjadi di perairan pantai yang kondisi lingkungannya buruk dan telah mengalami proses pengkayaan yang belebihan, sehingga status perairannya bersifat euthropic hingga hiperthrophic. Perairan yang telah mengalami pengkayaan berlebihan, kadar nutrientnya (nitrat, nitrit, ammonia dan phosphate) biasanya tinggi, sedangkan kadar oksigennya rendah. Hal ini banyak ditemukan di perairan muara sepanjang Teluk Jakarta hingga radius $10 \mathrm{~km}$ kearah lepas pantai Teluk Jakarta. Kondisi ini perlu diwaspadai karena apabila suhu perairan cukup hangat, salintas rendah dan laut dalam keadaan tenang, kejadian munculnya red tide dikawasan ini sangat potensial.

Untuk itu pemantauan atau monitoring beberapa parameter kunci seperti kadar oksigen (DO), temperatur dan salinitas secara terus menerus sangat diperlukan dalam mengantisifasi kemungkinan terjadinya red tide di perairan Teluk Jakarta. Red tide biasanya di indikasikan dengan perairan yang bewarna merah kecoklatan, tetapi ada pula yang tidak bewarna. Hal ini tergantung dari jenis phytoplankton yang mengalami ledakan populasinya. Kematian massal pada ikan dan biota perairan lainnya bisa juga diduga disebabkan oleh red tide. Hal ini harus dibuktikan dengan sampling kualitas air dan jenis plankton. Apabila terdapat populasi yang berlebihan dari plankton yang tergolong ke dalam penyebab red tide, maka dapat dikatakan bahwa perairan sedang atau telah mengalami red tide. Beberapa contoh indikasi perairan pantai yang sedang mengalami red tide terlihat pada gambar 24 .

\subsection{Alternatif Penanggulangan Red Tide}

Untuk menanggulangi masalah red tide, selain melakukan pembersihan dan perbaikan lingkungan perairan disepanjang pantai dan daerah aliran sungai (DAS) melalui pengerukan, pengurangan limbah organik dan limbah industri secara sistimatis, terencana dan terorganisir secara lintas sektoral dengan melibatkan seluruh komponen masyarakat yang hidup di DKI Jakarta dan BOTABEK, pemantauan kualitas lingkungan perairan secara periodik seperti telah dan sedang dilakukan BPLHD DKI Jakarta selama ini perlu ditingkatkan frekuensinya baik di permukaan maupun di dasar perairan.

Parameter penting yang merupakan parameter kunci penyebab terjadinya red tide seperti suhu perairan, salinitas, oksigen (DO), total organik matter (TOM), nitrat, nitrit, ammonia, phosphate, chlorophyll-a, plankton, BOD dan COD baik di permukaan maupun di dasar perairan perlu dilakukan pemantauan atau monitoring secara periodik. Mengingat peristiwa 
terjadinya red tide cukup sulit diperkirakan dan bisa terjadi dalan hitungan jam, pemantauan secara terus menerus terhadap beberapa parameter kunci penting yang terkait dengan indikasi terjadinya gejala red tide, seperti suhu perairan, salinitas, DO dan turbiditas atau kekeruhan sangat penting untuk dilakukan di perairan Teluk Jakarta terutama disekitar muara sungai sampai dengan radius $5 \mathrm{~km}$ kearah lepas pantai.

Untuk itu perlu dipasang perangkat monitoring kualitas air yang dapat merekam dan mengirim data serta informasi tentang keadaan perairan secara periodik ke pusat informasi di BPLHD untuk diolah dan dinalisa sesegera mungkin. Perangkat monitoring ini juga dapat berfungsi sebagai perangkat peringatan dini (early warning system) terjadinya gejala red tide, terutama apabila kita telah mengetahui peringkat yang sangat kritis untuk beberapa parameter kualitas air seperti suhu perairan, salinitas dan DO yang dapat memicu gejala terjadinya red tide. Dengan terpasangnya perangkat monitoring kualitas lingkungan perairan yang terus menerus mengirimkan data dan informasi tentang kondisi perairan, diharapkan penanganan masalah lingkungan, pencegahan pencemaran dan penanggulangan masalah red tide bisa dioptimalkan, sehingga resiko yang diakibatkannya dapat diminimalisir. Gambar 25 memperlihatkan model pemantauan kualitas perairan pantai secara online.

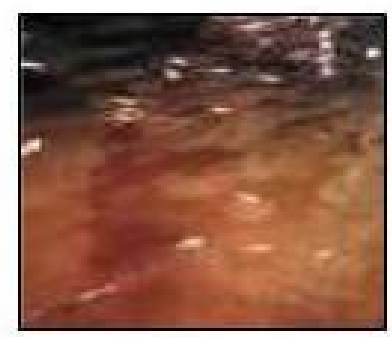

Florida Karenta brevis

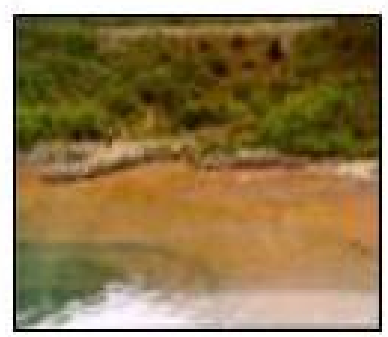

Hong Kong (Unidentified species)

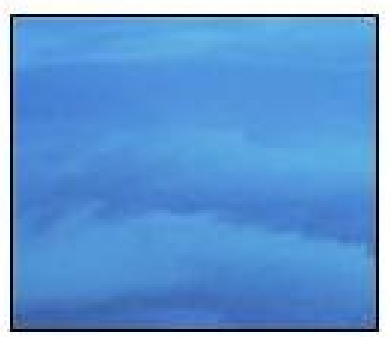

Chesapeake Bay Cochlodínium heterolobatum

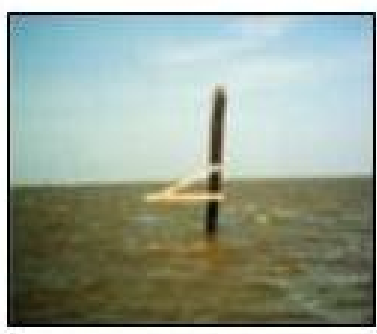

Texas Aureoumbra

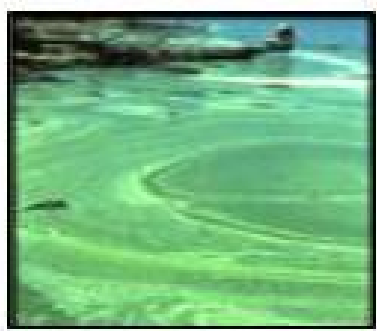

Nodularia spumigens Gippsland Lakes

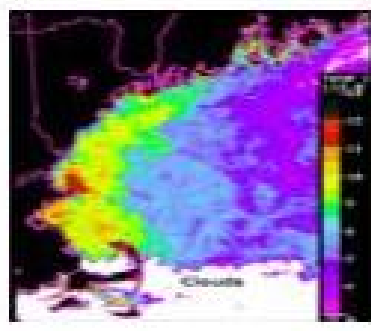

Alexandrium sp. bloom

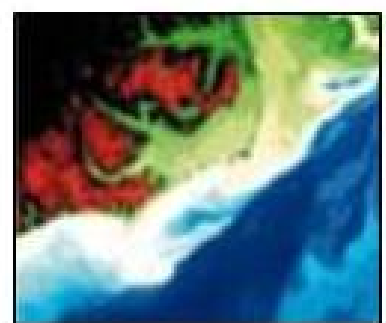

Karentia brevis

bloom

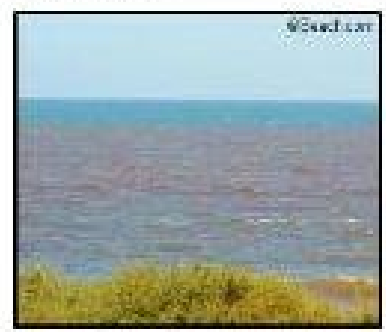

Red Tide

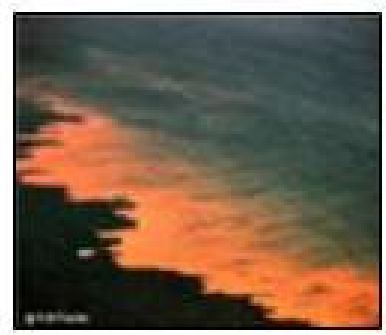

California Noctiluca

Gambar 24 : Indikasi Perairan Yang Sedang Mengalami Red Tide (Fryxell and Hasle, 2004). 


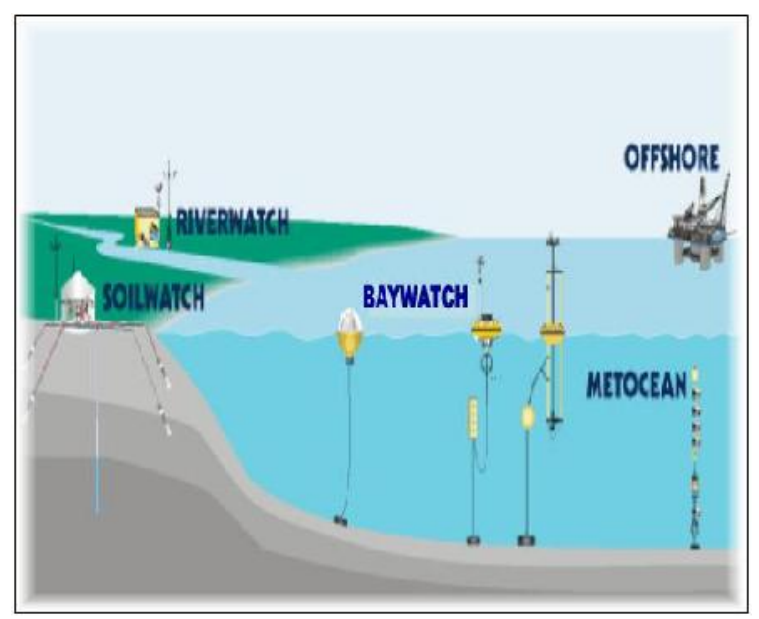

Gambar 25 : Model Pemantauan Kualitas Lingkungan Perairan Pantai.

\section{KESIMPULAN}

Dari uraian tulisan di atas dapat ditarik beberapa kesimpulan mengenai kondisi pencemaran di perairan teluk Jakarta, antara lain :

1. Pencemaran yang terjadi di Teluk Jakarta lebih banyak disebabkan oleh air limbah domestik masyarakat Jakarta yang membuang air limbahnya ke saluran drainase, kemudian mengalir ke sungai-sungai yang pada akhirnya bermuara ke perairan pantai utara Teluk Jakarta.

2. Air limbah domestik yang dibuang ke sungaisungai di Jakarta banyak mengandung detergen yang dapat menyebabkan tingginya beban pencemaran di sungai-sungai tersebut. Akibatnya kandungan deterjen dan BOD menjadi tinggi, sehingga kandungan oksigen (DO) di dalam air menjadi menipis.

3. Kondisi perairan Teluk Jakarta yang banyak mengandung limbah domestik menjadi penyebab utama kematian masal ikan bebarapa tahun belakangan ini. Air laut yang tercemar oleh air limbah domestik memiliki kadar oksigen terlarut (DO) yang sedikit, sehingga populasi phytoplankton dari jenis dinoflagellata yang bersifat toxic atau beracun menjadi bertambah banyak.

4. Hampir semua zona pangamatan (A, B, C, dan D) memiliki kualitas yang buruk. Kandungan oksigen terlarut (DO) di zona $A$ sebagai zona pengamatan terjauh dari pantai juga sudah berada di bawah baku mutu yang telah ditetapkan.

5. Kondisi lingkungan perairan pantai utara Jakarta yang buruk telah menyebabkan suatu proses euthrofikasi atau pengkayaan berlebihan di pantai ini, sehingga air laut di perairan ini menjadi bersifat euthropic.
6. Pada saat kejadian kematian masal ikan beberapa tahun lalu, perairan pantai di Teluk Jakarta bersifat euthropic, sehingga memiliki kadar nutrient yang tinggi, tetapi sebaliknya kadar oksigen (DO) terlarut dan salinitas air laut yang rendah. Pada saat terjadi kenaikan temperatur di permukaan air laut yang tenang, maka muncullah kejadian yang dikenal sebagai red tide dan diikuti dengan banyaknya ikan-ikan yang mati di tepi pantai.

\section{DAFTAR PUSTAKA}

1. JICA 1990, The Study On Urban Drainage and Waste Water Disposal Project In The City Of Jakarta.

2. Anonim 2004, Studi Pengembangan Ekosistem Laut di Kepulauan Seribu. Laporan Akhir. Kerjasama PT. Timas Planindo Dinamica dengan Dinas Peternakan, Perikanan dan Kelautan Provinsi DKI Jakarta.

3. BPLHD 2004 2005, Laporan status lingkungan hidup daerah Propinsi daerah khusus ibukota jakarta tahun 2004 2005.

4. Bates, S.S. Garrison, D.L. \& Horner, R.A. 1998. Bloom dynamics and physiology of domoic-acid-producing Pseudo-nitzschia species - In: Anderson, D.M., Cembella, A.D. \& Hallegraeff, G.M. (eds), Physiological ecology of harmful algal blooms, NATO ASI series, Series G, Ecological sciences, vol. 41, Springer-Verlag, Berlin, pp. 267-292, (see Books, pdf file NATO ASI)

5. Bates, S.S. 1998. Ecophysiology and metabolism of ASP toxin production - In: Anderson, D.M., Cembella, A.D. \& Hallegraeff, G.M. (eds), Physiological ecology of harmful algal blooms, NATO ASI series, Series G, Ecological sciences, vol. 41, Springer-Verlag, Berlin, pp. 405-426, (see Books, pdf file NATO ASI).

6. Fryxell, G.A. \& Hasle, G.R. 2004. Taxonomy of harmful diatoms. - In: Hallegraeff, G.M., Anderson \& D.M., Cembella, A.D. (eds), Manual on Harmful Marine Microalgae. Monographs on oceanographic methodology 11, Unesco, Paris, pp. 465-510.

7. Clément, A. \& Lembeye, G. 1993. Phytoplankton monitoring program in the fish farming region of South Chile. - In: Smayda, T.J. \& Shimizu, Y. (eds.). Toxic Phytoplankton Blooms in the Sea. Elsevier, New Cork, pp. 223-228.

8. Fryxell, G.A. \& Hasle, G.R. 2004. Taxonomy of harmful diatoms. - In: Hallegraeff, G.M., Anderson \& D.M., Cembella, A.D. (eds), Manual on Harmful Marine Microalgae. Monographs on oceanographic methodology 11, Unesco, Paris, pp. 465-510. 
9. Fryxell, G.A., Villac, M.C. \& Shapiro, L.P. 1997. The occurrence of the toxic diatom genus Pseudo-nitzschia (Bacillariophyceae) on the West Coast of the USA, 1920 -1996: a review. - Phycologia 36: 419-437.

10. Orsini, L, Sarno, D., Procaccini, G., Poletti, R., Dahlmann, J. \& Montresor, M. 2002. Toxic
Pseudo-nitzschia

multistriata

(Bacillariophyceae) from the Gulf of Naples: morphology, toxin analysis and phylogenetic relationships with other Pseudo-nitzschia species. - European J. Phycol. 37: 247-257.

\section{LAMPIRAN}

Tabel 3: Waktu Dan Lokasi Peristiwa Kematian Masal Ikan Di Teluk Jakarta.

\begin{tabular}{|c|c|c|c|c|c|}
\hline Tanggal & Kondisi & Lokasi & Jenis Ikan & Aksi & Hasil Analisa \\
\hline $\begin{array}{l}7 \mathrm{Apr} \\
2004\end{array}$ & $\begin{array}{l}\text { Air laut berwarna } \\
\text { kemerahan }\end{array}$ & \begin{tabular}{|} 
Pantai Ancol (M. \\
Bintang Mas-K \\
Japat) \\
Meluas ke P. \\
Nirwana, P. \\
Bidadari, P. Damar, \\
P. Onrus
\end{tabular} & \begin{tabular}{|} 
Kembung, Kue, \\
Sange, pari, \\
udang, kerang \\
hijau, rajungan
\end{tabular} & $\begin{array}{c}\text { Pengambilan sampel di } \\
\text { pantai Ancol }\end{array}$ & $\begin{array}{c}\text { Analisa Phytoplankton } \\
\text { menunjukan Blooming Algae } \\
\text { (Skeletonema Costatum 188 } \\
\text { jt sel/m3 - 76\%), penurunan } \\
\text { kadar oksigen terlarut }\end{array}$ \\
\hline $\begin{array}{c}30 \text { Nop } \\
2004\end{array}$ & $\begin{array}{l}\text { Air laut tenang } \\
\text { (pasang duduk) dan } \\
\text { malamnya terjadi } \\
\text { hujan, air berwarna } \\
\text { kecoklatan (tingkat } \\
\text { kekeruhan cukup } \\
\text { tinggi) }\end{array}$ & $\begin{array}{c}\text { Muara Marina } \\
\text { sampai Hotel } \\
\text { Horison }\end{array}$ & \begin{tabular}{|} 
Cunang, Krapu, \\
Baronang, Pari, \\
Sembilang, \\
Kakap, Udang, \\
Bandeng, \\
Rajungan
\end{tabular} & $\begin{array}{c}\text { Pengambilan sampel di } \\
\text { pantai sampai ke laut } \\
\text { dengan radius } 2 \mathrm{~km} \text { dari } \\
\text { pantai }\end{array}$ & \begin{tabular}{|} 
Penurunan oksigen terlarut \\
terjadi karena proses \\
degradasi dan dekomposisi \\
zat-zat organik (Phospat \& \\
Nitrat) yang melimpah di \\
perairan oleh bakteri \\
pengurai (aerob dan \\
anaerob) di perairan
\end{tabular} \\
\hline $\begin{array}{l}13 \mathrm{Apr} \\
2005\end{array}$ & Air laut keruh & $\begin{array}{l}\text { Hotel Horison, } \\
\text { Pantai Festival, } \\
\text { Pantai marina, } \\
\text { Pantai Karnaval }\end{array}$ & $\begin{array}{c}\text { Petek dan } \\
\text { cukang }(90 \%)\end{array}$ & $\begin{array}{c}\text { Pengambilan sampel di } \\
\text { pantai ancol sampai ke } \\
\text { laut dengan radius } 4 \mathrm{~km} \\
\text { dari pantai }\end{array}$ & \begin{tabular}{|} 
- Penurunan kandungan \\
oksigen terlarut $(<5 \mathrm{mg} / \mathrm{L})$, \\
terjadi pengayaan unsur \\
hara (eutrofikasi) - Terjadi \\
blooming algae \\
(Stephanopyxis $12.109 \mathrm{sel} / \mathrm{tt}$ \\
- 86.5\%) merupakan jenis \\
fitoplankton yang tidak \\
beracun
\end{tabular} \\
\hline $\begin{array}{l}15 \text { Jun } \\
2005\end{array}$ & $\begin{array}{l}\text { air laut keruh, dan } \\
\text { pada saat tersebut } \\
\text { terjadi hujan lebat }\end{array}$ & \begin{tabular}{|c} 
Pantai Marina, \\
Pantai Festival, \\
Pantai H. Mecure, P. \\
Bandar Jakarta, \\
Pantai Karnaval
\end{tabular} & $\begin{array}{l}\text { Udang, } \\
\text { Rajungan, } \\
\text { cukang, } \\
\text { sembilang, } \\
\text { petek }\end{array}$ & $\begin{array}{c}\text { Pengambilan sampel di } \\
\text { pantai Ancol }\end{array}$ & $\begin{array}{c}\text { Kadar Oksigen Terlarut } \\
\text { rendah }\end{array}$ \\
\hline $\begin{array}{l}5 \text { Agt } \\
2005\end{array}$ & \begin{tabular}{|c|} 
Air laut berwarna \\
coklat kemerahan, \\
dimana sample air laut \\
di pinggir pantai \\
berwarna coklat, \\
sample air laut di \\
tengah laut berwarna \\
merah \\
\end{tabular} & \begin{tabular}{|} 
Pulau Zukung \\
Sekati, P. \\
Panggang, P. \\
Pramuka, P. Karya
\end{tabular} & $\begin{array}{c}\text { tidak ditemukan } \\
\text { ikan mati }\end{array}$ & $\begin{array}{c}\text { Menganalisa sampel } \\
\text { yang dikirim oleh Sudin } \\
\text { Perhubungan Kep. } \\
\text { Seribu }\end{array}$ & \begin{tabular}{|} 
Ditemukan adanya plankton \\
Trichodesmium, yang \\
merupakan jenis algae \\
beracun, menyebabkan \\
kesemutan di mulut, jari \\
tangan, kaki, muntah2, sakit \\
pada persendian
\end{tabular} \\
\hline $\begin{array}{l}160 \mathrm{Okt} \\
2005\end{array}$ & $\begin{array}{c}\text { Air laut keruh, Sore } \\
\text { hari }(15 / 10) \text { terjadi } \\
\text { hujan deras }\end{array}$ & Pantai Ancol & tidak ada data & & $\begin{array}{l}\text { ikan belum mati tetapi } \\
\text { mabuk dan menepi ke } \\
\text { pantai Ancol }\end{array}$ \\
\hline
\end{tabular}

